Effects of Non-Ionizing Radiation and its Health Hazards on human body

Runak Tahir Ali and Abdulrahman Khaleel

\title{
Effects of Non-Ionizing Radiation and its Health Hazards on human body
}

\author{
Runak Tahir Ali* $^{*}$, Abdulrahman Khaleel ${ }^{* *}$ and Ismael Hussain Rasool ${ }^{* *}$ \\ *Hawler Medical University-Erbil- Iraq \\ ${ }^{* *}$ Collage science - Physics - University of Salahaddin- Erbil-Iraq \\ Received 6 May 2016 ; Accepted 25 August 2016
}

\begin{abstract}
$\underline{\text { Abstract }}$
The electromagnetic pollution is produced from the electromagnetic radiation source. In recent years, there is electromagnetic pollution in our earth. Different types of source are caused these pollution such as mobile phones, tower lines, and Wi-Fi. The increase of using these devices will lead to increase various problem of public health. The aim of this study was to evaluate the effects of nonionizing radiation and its health hazards on human body. Various data (the power density) were collected from two types of mobile phones, tower cells, photocopy machine, power lines, D-Link wireless and fast link. Data from a school were also collected. Charts and tables of each data were given. It has been found that the increased use in the electromagnetic devices such as mobile phones galaxy and I phone, cell towers, will have extremely negative effect on human health. It has also been found that using mobile phones with the full charge has less intensity than with low charge. It can be concluded from mobile and cell tower data that the exposure limit of RF was lower than the standard RF of Iraq. Further research in a wider level will be required to investigate all type of mobile phones that are used in our city and their effects on human health.
\end{abstract}

Key words: Cell tower, Mobil phone, Non ionizing radiation\& human health. 


\title{
Effects of Non-Ionizing Radiation and its Health Hazards on human body
} Runak Tahir Ali and Abdulrahman Khaleel

\author{
تأثير الأشعاعات غير المؤينة والمخاطر الصحية على جسم الانسان \\ رووناك طاهر على" ، عبدالرحمان خليل سليمان ** سماعيل حسين رسول** \\ جامعة هولير الطبية ـ كلية الطب ـ قسم الفيزياء الطبية

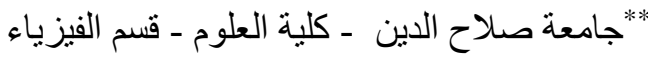

\begin{abstract}
الخلاصة
فى السنوات الأخيرة هناك تلوث الكهرومغناطيسى فى أرضنا ، ونتسبب لأنو اع مختلفة من مصادر هذه التلوث مثل الهو اتف النقالة و خطوط البرج و خدمة الواى فاى. إن فى زيادة استخدام هذه الأجهزة يؤدى إلى زيادة مشاكل مختلفة فى صحة الأنسان. وكان الهدف من هذه الدر اسة هو تقييم أثنار الأشعاع و المخاطر الصحية على جسم الأنسان ـ تم جمع البيانات ( كثافة

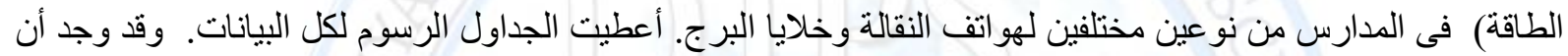
زيادة إستخدام الأجهزة الكهرومغناطيسية مثل الهو اتف النقالة و أبر اج المكالمة سوف يكون لها تأثثير سلبى للغاية على صحة الانسان ، وقد تبين أيضاً أن إستخدام الهو اتف المحمولة مع كامل الثحن له أقل كثافة مقارنة مع محمول إنخفاض مستوى إنى الثحن. يمكن الآستتناج من البيانات للهو اتف المتنقلة وبرج الخلية أن الحد من التعرض للترددات الأشعاعية كان أقل من الترددات الآشعاعية القياسية دولياً فى العراق. سوف تكون هناك حاجة إلى مزيد من البحوث فى نطاق أوسع للتحقيق فى في كل نوع من الهو اتف النقالة التى تستخدم فى مدينتناو أثنار ها على صحة الانسان. الكلمات المفتاحية: خطوط الابر اج، الهو اتف النقالة، تأين غير الاشعاعى و صحة الانسان
\end{abstract}

\section{$\underline{\text { Introduction }}$}

Electromagnetic fields are energy waves with frequencies below 300 hertz (cycles per second) we are exposed to a virtual array of harmful EMFs known as electromagnetic pollution or radiation 24 hours a day. Wireless technology is based on extensive networks of base stations that connect the users through Radio Frequency (RF) signals. Over the last decade, there has been a great deal of concern about possible health consequences caused by human exposure to $\mathrm{RF}$ in general and radiations from base stations in particular ${ }^{[1]}$. Electromagnetic radiation, in the form of waves of electric and magnetic energy, have been circulating together through 


\section{Effects of Non-Ionizing Radiation and its Health Hazards on human body}

Runak Tahir Ali and Abdulrahman Khaleel

space. The electromagnetic spectrum includes radio waves, microwaves, infrared rays, light rays, ultraviolet rays, X-rays, and gamma rays ${ }^{[2]}$. The IEEE and many national governments have established safety limits for exposure to various frequencies of electromagnetic energy based on SAR ${ }^{[3]}$ Using a cellular telephone was associated with a risk of having a motor vehicle collision that was about four times as high as that among the same drivers when they were not using their cellular telephones. In some parts of the world, mobile phones are the most reliable or the only phones available ${ }^{[4]}[5]$. A mobile phone is designed to transmit radio waves in all directions because base stations could be in any direction with respect to phone users. This means that a proportion of the radio waves they produce are directed towards the user's body

[6]. Damage to tissue can be caused by exposure to radio frequency radiation because the body is not equipped to dissipate excessive amounts of heat. The eyes are particularly vulnerable due to the lack of blood flow in that area ${ }^{[7]}$. When talking on a mobile phone, most users place the phone against the head. In this position, there is a good chance that most of the radiation will be absorbed by human tissue ${ }^{[8]}$. Wireless telecommunications rely on a wide network of cell phone towers (base stations) to send and receive information. Cell phone towers consist of antennas and electronic equipment which serve as hubs for cell phones and local wireless networks ${ }^{[9]}$. The 3 expert agencies that usually classify cancer-causing exposures (carcinogens) - the International Agency for Research on Cancer (IARC), the National Toxicology Program (NTP), and the US Environmental Protection Agency (EPA) - have not classified cell phone towers as to their cancer-causing potential ${ }^{[10]}$.Figure [1] Enjoy high speed ADSL2+ internet connection and up to $300 \mathrm{Mbps}$ wireless data transfer speed with this high-performance D-Link wireless router with modem ${ }^{[11]}$. 
Effects of Non-Ionizing Radiation and its Health Hazards on human body

Runak Tahir Ali and Abdulrahman Khaleel

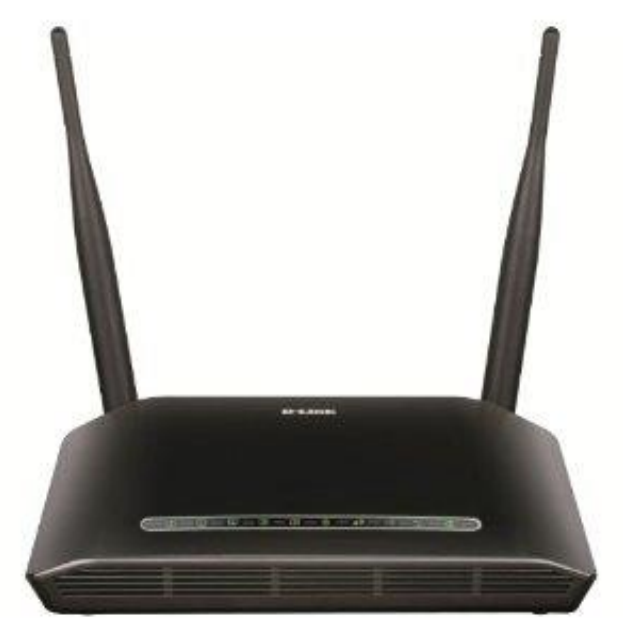

Figure 1. ADSL device

\section{B-High-voltage transmission lines}

High-voltage transmission lines are used to transmit electric power over relatively long distances, usually from a central generating station to main substations ${ }^{[12]}$. Figure [2] the $4 \mathrm{G}$ LTE portable Wi-Fi routers "MiFi" provides you with the opportunity to enjoy the fastest, and most reliable wireless internet access anytime anywhere ${ }^{[13]}$.

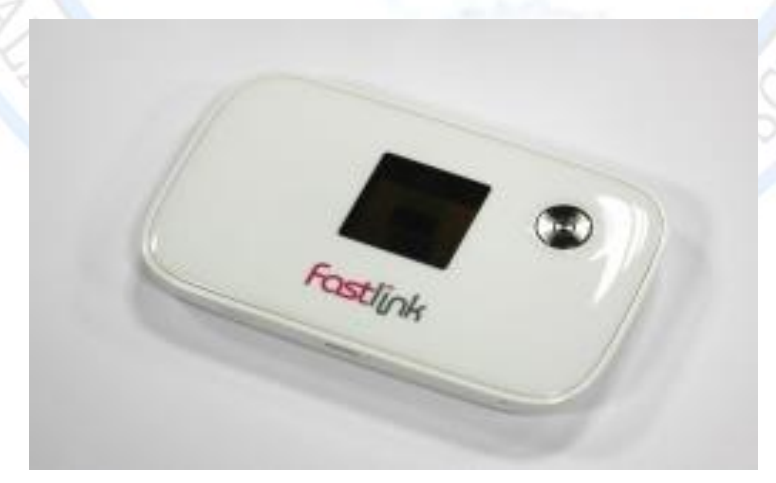

Figure 2. Fast link devices

It is important to know the safety limit of radiation exposed of the human body. Table 1 .

Showed the report safe limit for different scientific center ${ }^{[14]}$. 
Effects of Non-Ionizing Radiation and its Health Hazards on human body Runak Tahir Ali and Abdulrahman Khaleel

Table 1. Exposure limits of the radiofrequencies of fields 900 and $1800 \mathrm{MHz}^{[15]}$.

\begin{tabular}{|c|c|c|}
\hline Organizations & $\begin{array}{c}\text { Exposure limits } \\
\text { for RF fields } \\
(\mathbf{9 0 0 M H z})\end{array}$ & $\begin{array}{c}\text { Exposure limits } \\
\text { for RF fields } \\
(\mathbf{1 8 0 0 M H z})\end{array}$ \\
\hline BUND recommendation 1997 & $0.045 \mu \mathrm{W} / \mathrm{cm}^{2}$ & $0.09 \mu \mathrm{W} / \mathrm{cm}^{2}$ \\
\hline "Precautionary limit" in Austria & $0.1 \mu \mathrm{W} / \mathrm{cm}^{2}$ & $0.1 \mu \mathrm{W} / \mathrm{cm}^{2}$ \\
\hline Exposure limit in Russia & $2 \mu \mathrm{W} / \mathrm{cm}^{2}$ & $2 \mu \mathrm{W} / \mathrm{cm}^{2}$ \\
\hline ECOLOG-recommendation 1998(Germany) & $4.5 \mu \mathrm{W} / \mathrm{cm}^{2}$ & $9 \mu \mathrm{W} / \mathrm{cm}^{2}$ \\
\hline Exposure limit in Poland & $10 \mu \mathrm{W} / \mathrm{cm}^{2}$ & $10 \mu \mathrm{W} / \mathrm{cm}^{2}$ \\
\hline Exposure limit in Italy & $16 \mu \mathrm{W} / \mathrm{cm}^{2}$ & $16 \mu \mathrm{W} / \mathrm{cm}^{2}$ \\
\hline Exposure limit in CSSR & $24 \mu \mathrm{W} / \mathrm{cm}^{2}$ & $24 \mu \mathrm{W} / \mathrm{cm}^{2}$ \\
\hline Exposure limit in Iraq & $400 \mu \mathrm{W} / \mathrm{cm}^{2}$ & $400 \mu \mathrm{W} / \mathrm{cm}^{2}$ \\
\hline Exposure limit in New Zealand & $200 \mu \mathrm{W} / \mathrm{cm}^{2}$ & $200 \mu \mathrm{W} / \mathrm{cm}^{2}$ \\
\hline Exposure limit in Canada (Safety Code 6, 1997) & $300 \mu \mathrm{W} / \mathrm{cm}^{2}$ & $300 \mu \mathrm{W} / \mathrm{cm}^{2}$ \\
\hline Exposure limit in Germany and ICNIRP & $450 \mu \mathrm{W} / \mathrm{cm}^{2}$ & $900 \mu \mathrm{W} / \mathrm{cm}^{2}$ \\
\hline recommendation 1998 & & \\
\hline
\end{tabular}

\section{Material Methods}

This study was performed in Erbil capital city of Kurdistan Region Government-Iraq. We measured the power density of three cell towers, a power line, photocopy machines and a WiFi by using the device of Electromagnetic Field strength meter (Extech 480846 RF/EMF Strength Meter) as shown in figure 3. This device was provided by the Erbil Environment Directorate. 
Effects of Non-Ionizing Radiation and its Health Hazards on human body

Runak Tahir Ali and Abdulrahman Khaleel

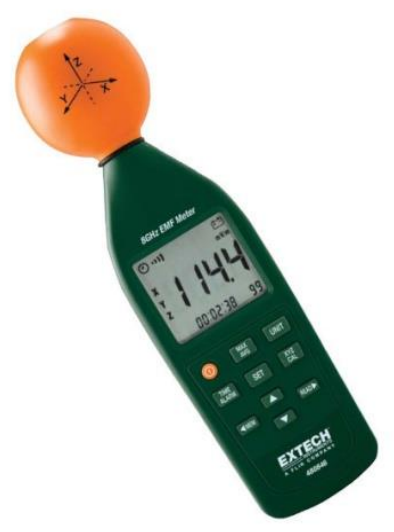

Figure 3. Electromagnetic strength meter

For electromagnetic field strength device measurement including:

-Mobile phone base station antenna radiation

-RF power measurement for transmitters

-Wireless LAN (Wi-Fi) detection/installation

-Wireless communication applications (CW, TDMA, GSM, DECT)

-Microwave leakage.

Data was collected from a primary school [Qazi Mohammed] in normal socioeconomic situation area in Erbil to know how many pupils were hold a mobile from one to six stages. The total number of pupil in this school was 360 pupils.

\section{$\underline{\text { Results and Ddiscussion }}$}

Figure [4] shows the intensity of mobile phones as a function of the distance of both ringing and speaking for both full charge and low charge buttery. The average time of ringing and speaking that considered in this study was 15 seconds. It can be seen that the density is decreasing as the distance is increasing. At zero distance, the density of both time of ringing and speaking are high for low charge battery while this density are low where the distance of 
Effects of Non-Ionizing Radiation and its Health Hazards on human body

Runak Tahir Ali and Abdulrahman Khaleel

both speaking and ringing are 15 centimeter. The differences in density between full charge and low charge battery in both ringing and speaking at for instance 7 centimeters is high while this difference is lower at the 15 centimeter distance.

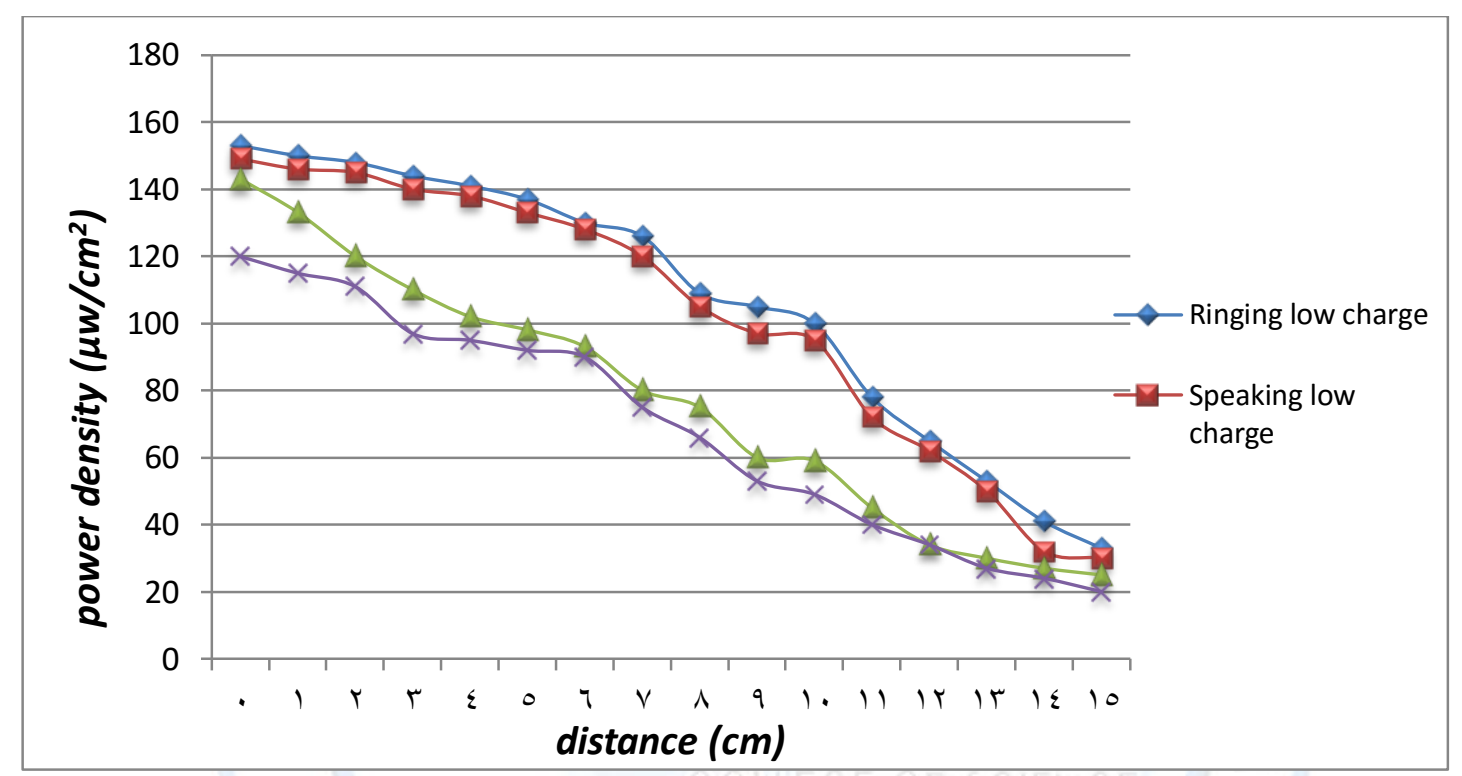

Figure 4. The intensity of mobile phones as a function of the distance of both ringing and speaking for both full charge and low charge.

Illustrates the difference in density between iPhone and Samsung mobiles at low charge in the time of ringing showing in the figure 5. It can be noted that the density of I phone mobile are much higher than Samsung galaxy. However, the density of both types of mobile phones is decreasing as the distances are increasing. 
Effects of Non-Ionizing Radiation and its Health Hazards on human body Runak Tahir Ali and Abdulrahman Khaleel

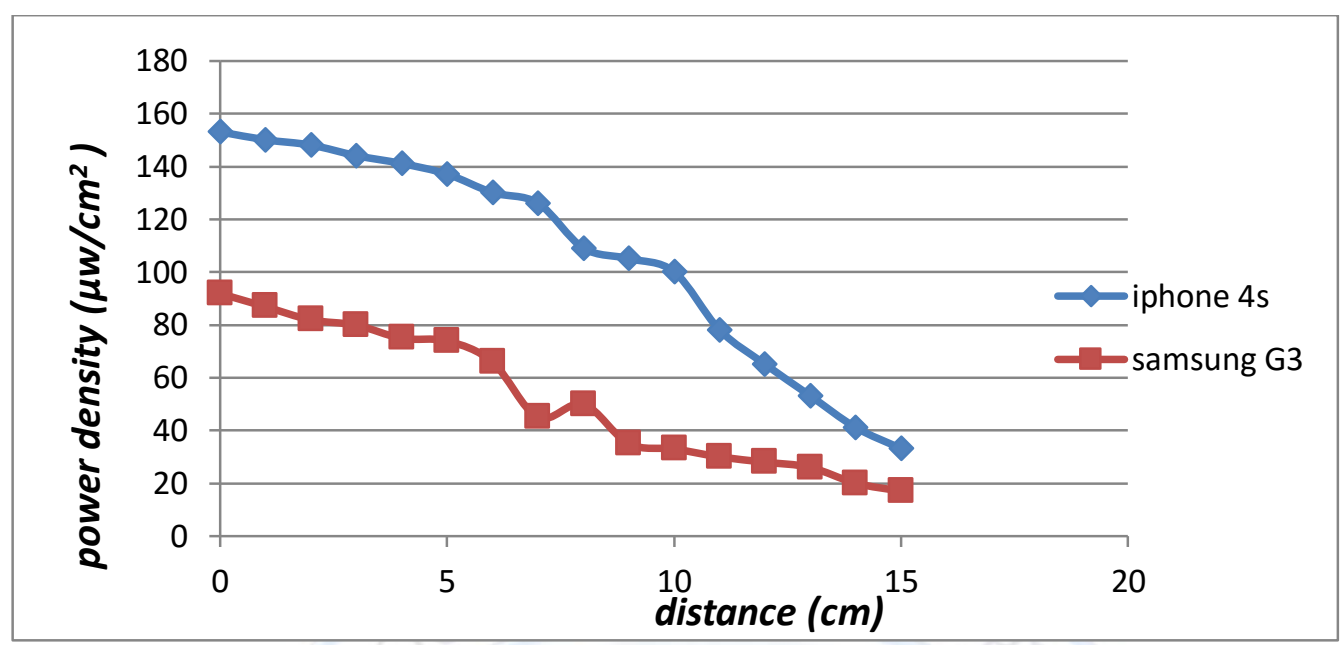

Figure 5. The density of I phone and Samsung mobiles at low charge as a function of the distance.

Figure 6. Illustrates the intensity of four sides of cell towers by distance. In the zero distance, intensities of cell towers in the four sides are almost the same. In distance of 75 meters, south side of cell towers has the highest intensity which is about $1.22 \mu \mathbf{w} / \mathbf{c m}^{2}$. This is because of the fact that the number of antenna in this side was more than the other sides.

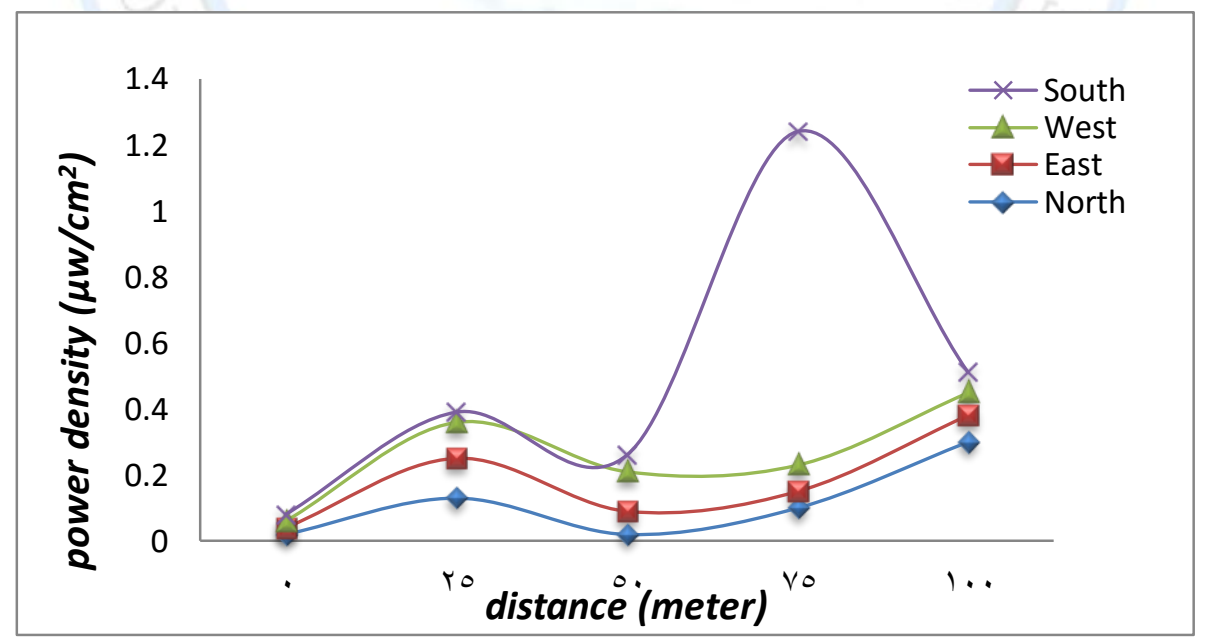

Figure 6. The intensity of cell towers by distances in its four sides in Zelan quarter in Erbil. 
Effects of Non-Ionizing Radiation and its Health Hazards on human body

Runak Tahir Ali and Abdulrahman Khaleel

The intensity of four sides of cell towers by distance in Zanko 2 quarter in Erbil showed in the Figure 7. In the zero distance, intensities of cell towers in the four sides are almost the same. In distance of 50 meters, south east side of cell tower has the highest intensity which is about $0.8 \mu \mathbf{w} / \mathbf{c m}^{2}$. This is because of the fact that the number of antenna in this side was higher than the other sides. However, North West side of cell tower has the highest intensity which is about $0.7 \mu \mathbf{w} / \mathbf{c m}^{2}$ and south west side of the cell tower has the lowest intensity throughout the distances

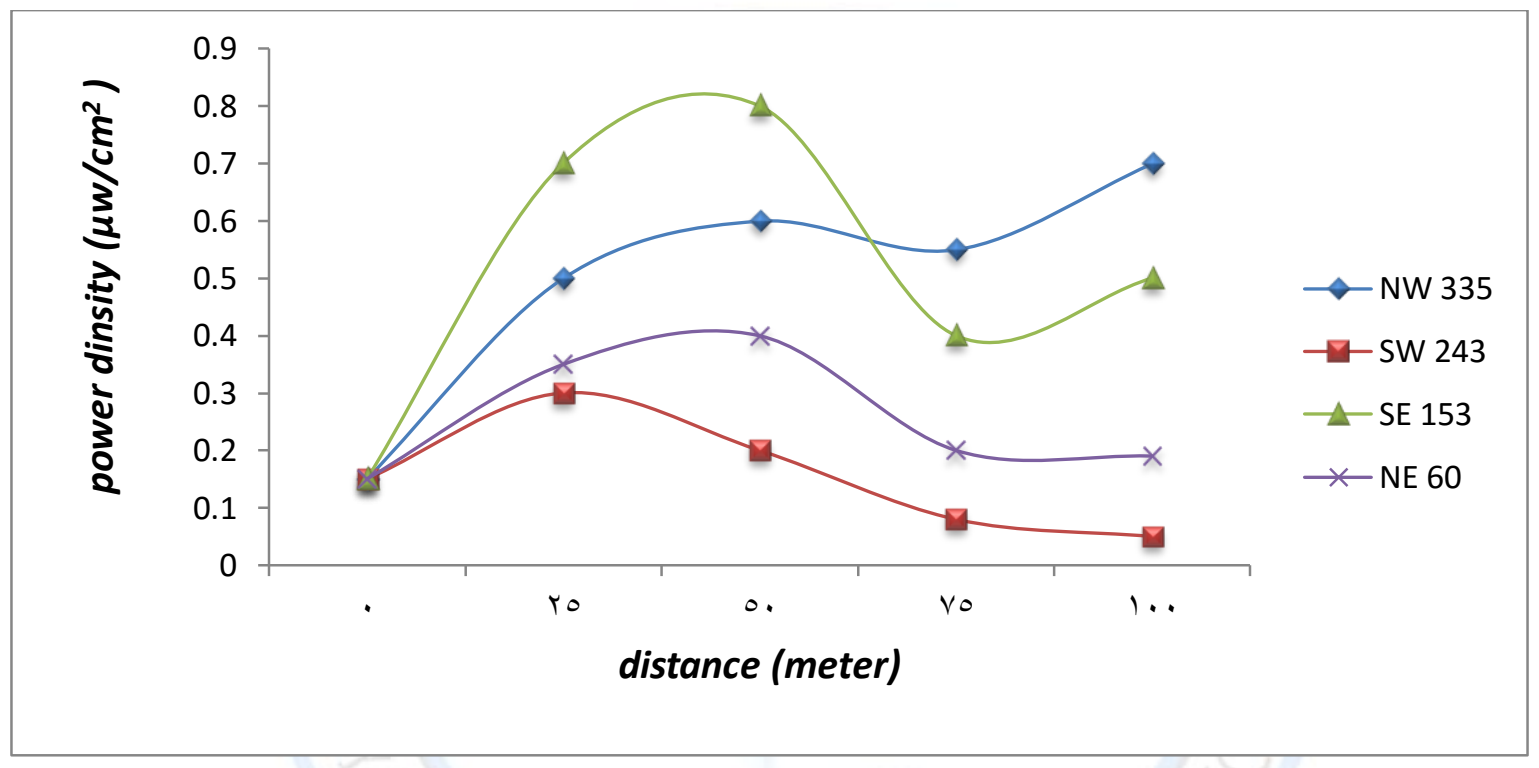

Figure 7. The intensity of cell towers by distances in its four sides in Zanko 2 quarter in Erbil.

Measurement the intensity of cell towers in Hamren quarter in Erbil. Figure 8.shows the intensity of cell power in the north east side is the highest than the other sides. This is because the cell tower has more antennas in this side than others. Moreover, south west side of cell tower has lower intensity. Experts of communication say that as the number of mobile users is increasing in one cell tower, the radio frequency will be increased. This means that the negative effect of radio frequency will be increasing. 
Effects of Non-Ionizing Radiation and its Health Hazards on human body Runak Tahir Ali and Abdulrahman Khaleel

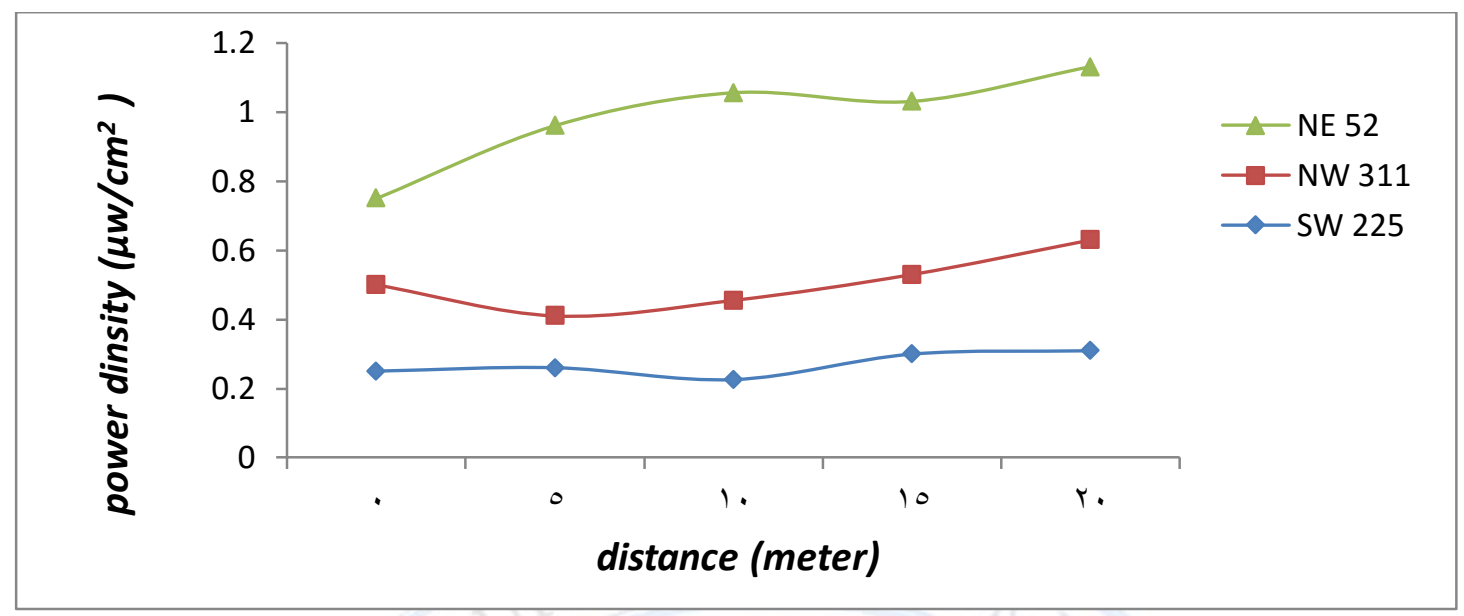

Figure 8. The intensity of cell towers by distances in its four sides in Hamren quarter in Erbil.

Figure 9 shows the intensity of Wi-Fi that measured in its four sides. It can be shown that the intensity of $\mathrm{Wi}-\mathrm{Fi}$ at $0 \mathbf{~ c m}$ distance in right side is higher the other sides. This is because that most users were in the right side of Wi-Fi. The intensities of Wi-Fi for all sides at $100 \mathbf{c m}$ distance are almost the same.

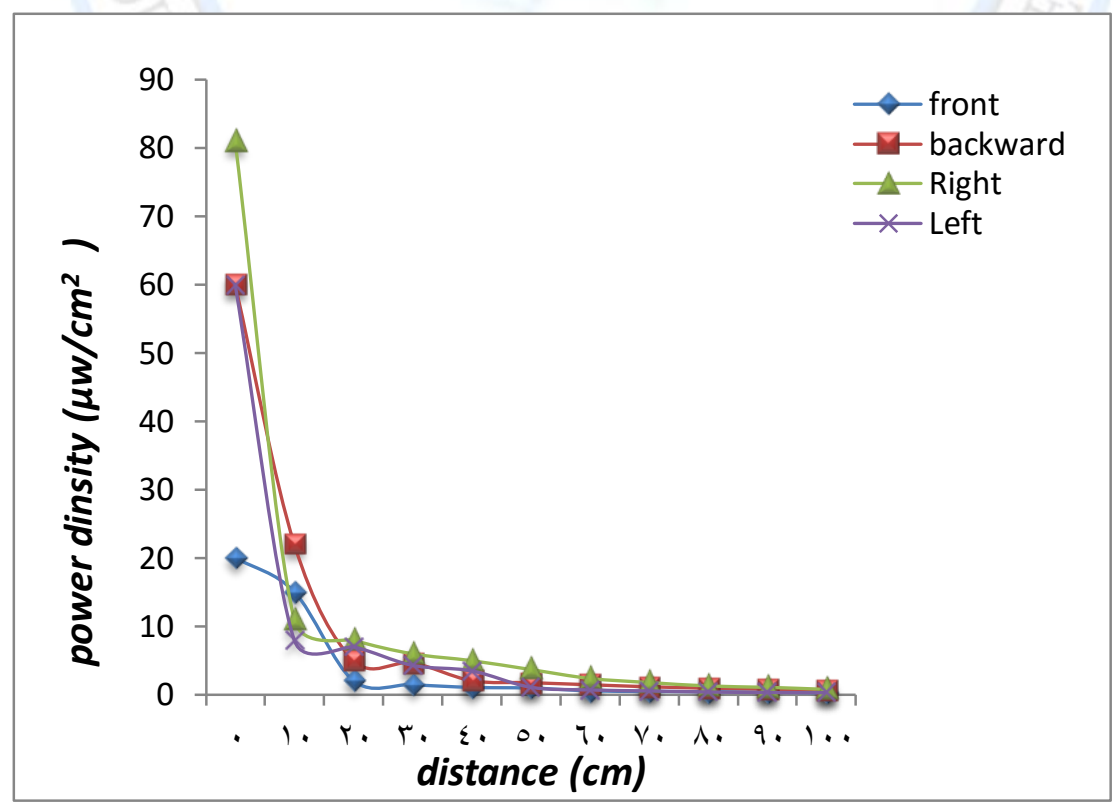

Figure 9. Intensity of Wi-Fi measure by four sides when there are 4 users. 
Effects of Non-Ionizing Radiation and its Health Hazards on human body

Runak Tahir Ali and Abdulrahman Khaleel

The intensity of Wi-Fi that measured in its four sides as shown in Figure 10. It can be shown that the intensity of $\mathrm{Wi}-\mathrm{Fi}$ at $0 \mathbf{c m}$ distance in right side is higher the other sides. The intensities of Wi-Fi for all sides at $100 \mathbf{c m}$ distance are almost the same. It can be concluded that intensity of $\mathrm{Wi}-\mathrm{Fi}$ is higher when the number of users is increased.

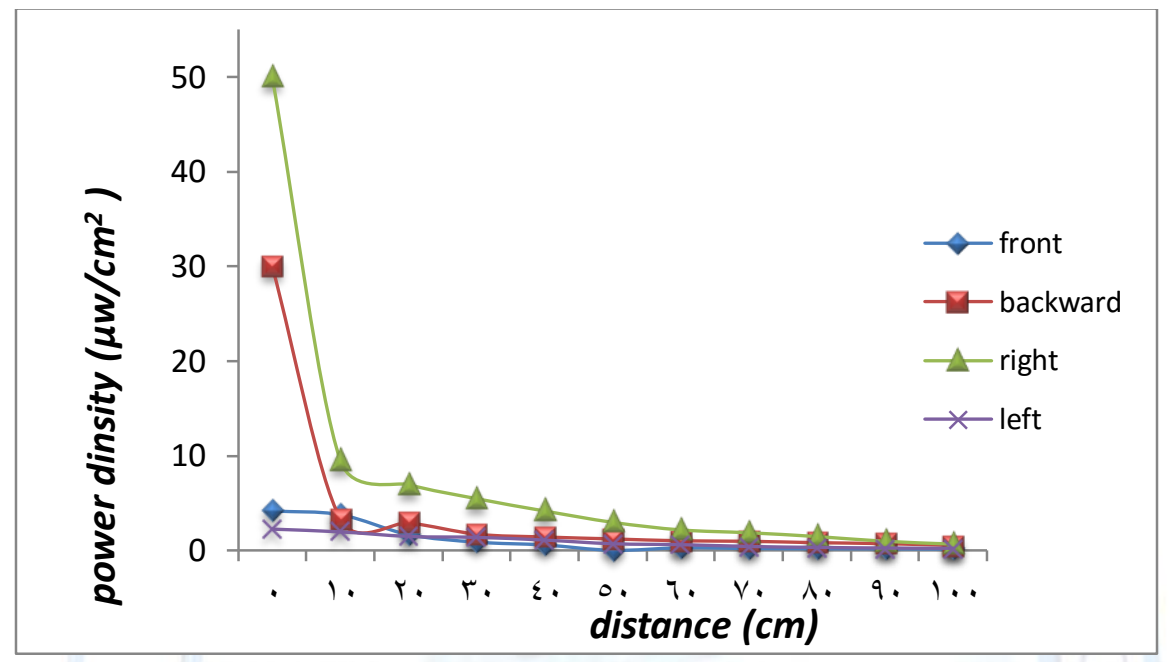

Figure 10. Intensity of Wi-Fi measure by four sides when there are no users

Figure [1] below shows the intensity of fast link device by distance. It can be seen that the density is decreasing as the distance is increasing

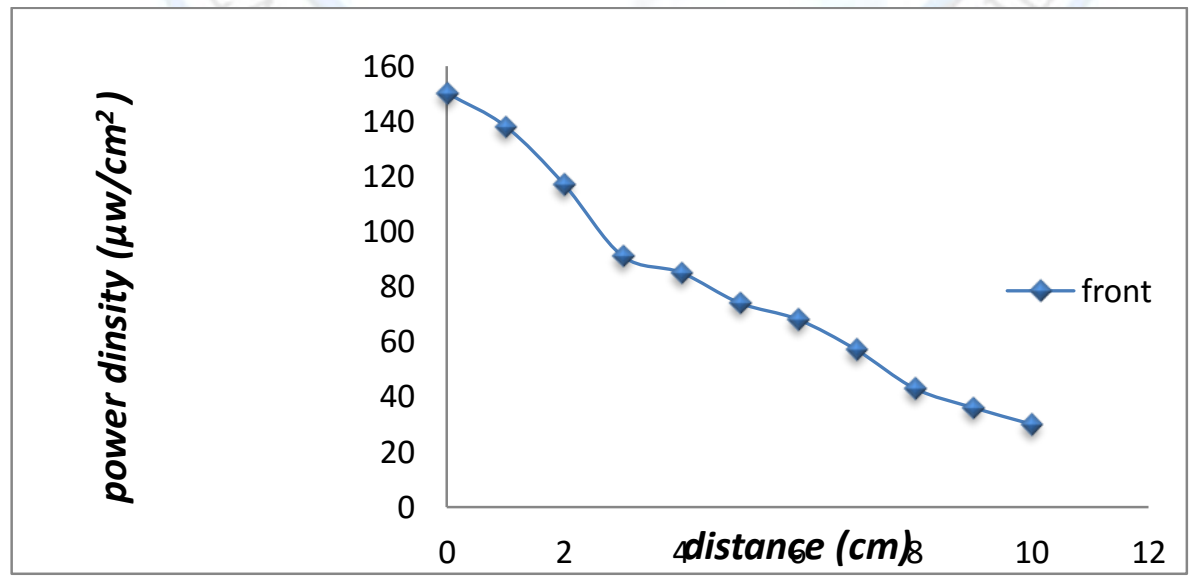

Figure 11. Intensity of fast link measure by in front. 
Effects of Non-Ionizing Radiation and its Health Hazards on human body

Runak Tahir Ali and Abdulrahman Khaleel

The intensity of radiation emitted from photocopy machines with distance measured as shown in figure 12. Only one photocopy machine was taken into account in this study this is because it has been thought that most of the photocopies are the same. It can be shown that the intensity of radiation emitted from photocopy in the front side in the zero distance is significantly higher than the above side of photocopy. However, the intensity is decreased when the distance is increased. In distance of $30 \mathrm{~cm}$, the intensity of both above and front sides are similar. The intensity of radiation emitted from photocopy, that is comparable to the standard safety range, is lower.

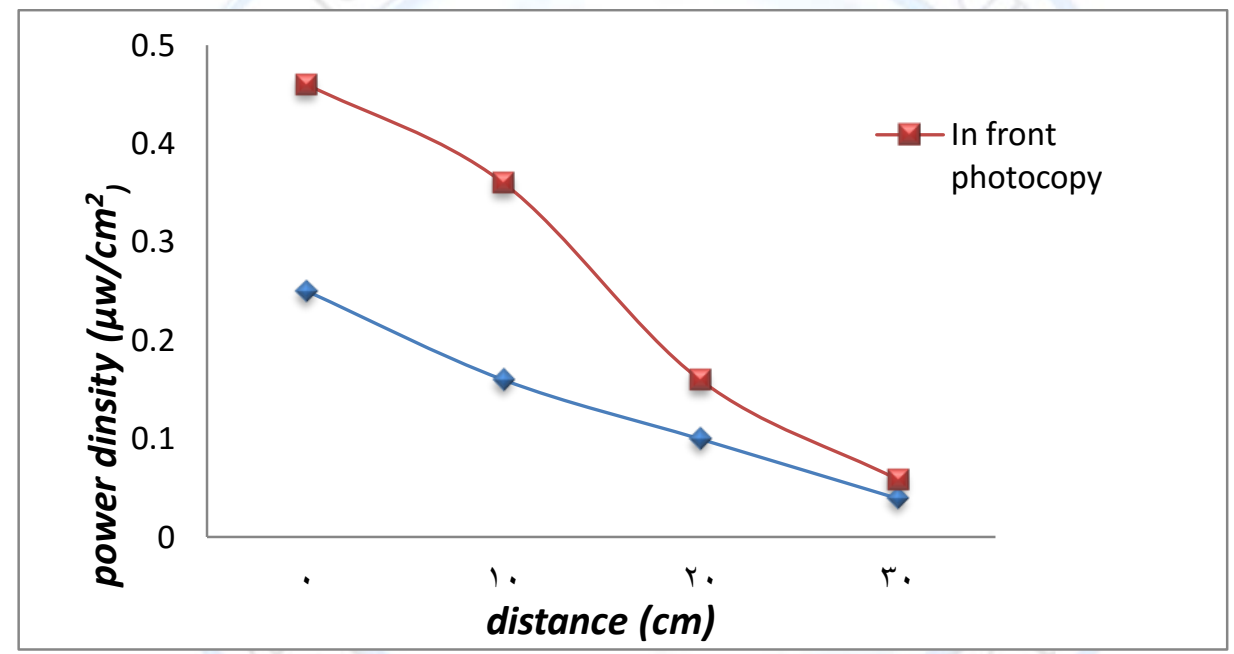

Figure 12. Intensity of radiation emitted from photocopy measure by in front and above.

The total number of pupil in this school was 360 pupils. The school was deeded into six stages from 1 to6 it can be seen that the higher stages the pupils are, the more mobile phones are used. Out of 360 pupils, 92 pupils had mobile phones in all stages. $33.3 \%$ of pupils from stage six are used mobile phones. 
Effects of Non-Ionizing Radiation and its Health Hazards on human body Runak Tahir Ali and Abdulrahman Khaleel

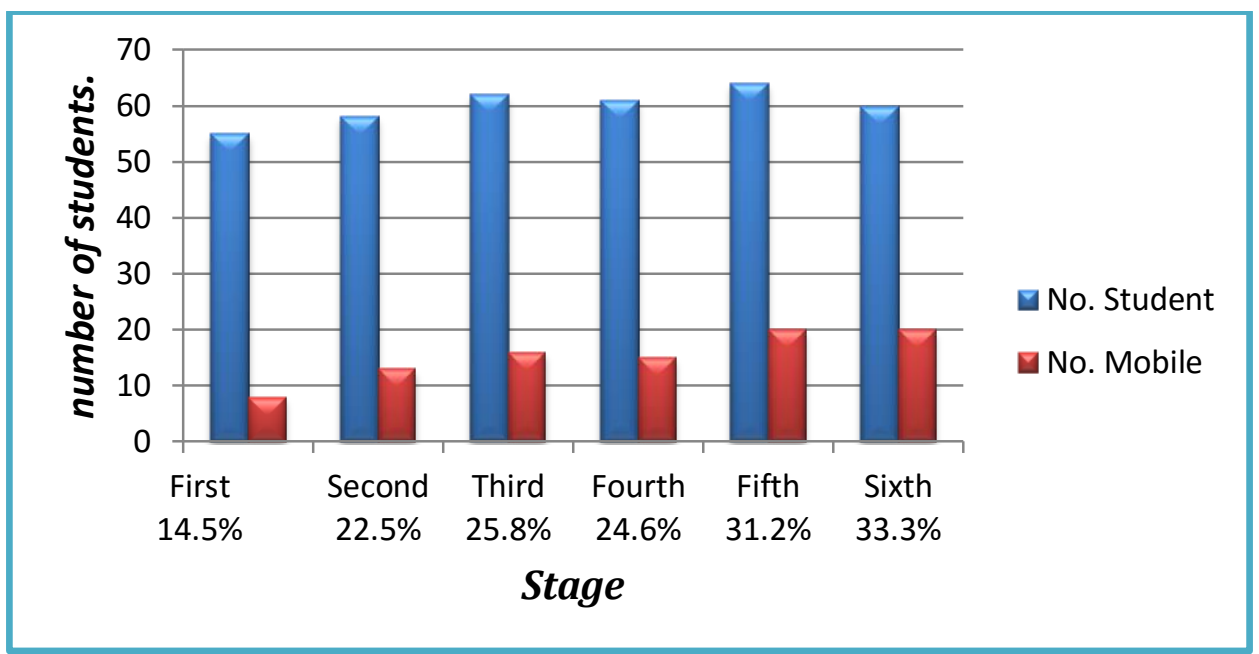

Figure 13. Numbers of pupils and mobile phones by stages

\section{Conclusions}

1- It can be concluded from mobile data that the exposure limit of RF was lower than the standard RF of Iraq. However, the RF of I phone 4s was higher than Samsung galaxy mobile. This means that using I phone mobile is more dangerous than Samsung galaxy mobile.

2- Additionally, the results of cell towers and photocopy machines in general were under the standards. However, this does not mean that the cell towers and photocopy machines do not have negative effects on public health.

3- In term of the effect of ADSL Wi-Fi, when the distance below the 40 centimetre is under the standard limits (have lower RF than standards), but it would be much better if the distance of ADSL is more than 100 centimetres. Moreover, when the number of users of $\mathrm{RF}$ is increasing, the exposure limits of RF are also increasing. The density of Fast-link Wi-Fi was measured every one centimetre because people usually hold their Fask-links in their pockets. The RF of Fask-link was much higher than the standards. Thus, it would be better that keep the distances away from users when they use Fast-link. 


\section{Effects of Non-Ionizing Radiation and its Health Hazards on human body}

Runak Tahir Ali and Abdulrahman Khaleel

4- The results of Qazi-Muhammed school can be summarized that the more stages were, the more mobile phone pupils were used. Additionally, as the ages of patients were higher, the probability of getting brain cancer was higher. The proportion of people who may get brain cancer would be increasing annually

Recommendations and further research:

It is believed that these findings will be applicable in a wider level. Some recommendation will be given in order to caution people to be aware of. Recommendations are as follows,

1- Reduce using mobile phones, use only if it is necessary

2- Use speakers to keep mobile away from users

3- Try to use mobile messages more than callings

4- Try not speaking in your mobile more than two minutes. If you use more than two minutes, try to change the location.

5- Do not hold devices such as mobile phones, Fast-link, ..,etc in the pocket near heart.

6- Holding mobile phones by children has negative effects on their health, so it is dangerous to them to hold mobiles.

7- People should not sit near Wi-Fi devices.

8- Patients who have brain cancer should not hold or use mobile phones. 


\section{Effects of Non-Ionizing Radiation and its Health Hazards on human body}

Runak Tahir Ali and Abdulrahman Khaleel

\section{$\underline{\text { References }}$}

1. Lalrinthara Pachuau\& Zaithanzauva Pachuau (2014)" Study of Cell Tower Radiation and its Health Hazards on human body" IOSR Journal of Applied Physics (IOSR-JAP) eISSN: 2278-4861. Volume 6, Issue 1 Ver. PP 01-06 www.iosrjournals.org.

2. S. Sivani \& D. Sudarsanam" (2013) Impacts of radio-frequencelectromagnetic field (RF-EMF) from cell phone towers and wireless devices on biosystem and ecosystem "J. Biology and Medicine, 4 (4): 202-216, 2012www.biolmedonline.com.

3. Sunu Mani, A Report on Electromagnetic radiations and ITS effects on Humans in nitc, National Institute of Technology, University Calicut.

4. Donalda R. \& Robertj T. (1997) “ASSOCIATION BETWEEN CELLULARTELEPHONE CALLS AND MOTOR VEHICLECOLLISIONS” The New England Journal of Medicine VOLUME 336 FEBRUARY13.

5. Muoaaz Nahas, Mohammed T. Simsim, (2011) Safety Measurements of Electromagnetic Fields Radiated form Mobile Base Stations in the Western Region of Saudi Arabia, Wireless Engineering Technology, 221-229.

6. Sabah Hawar Saeid, (2012) "Human Exposure Assessment in the Near-Field of Antennas Used by Mobile Phone Devices”, Journal of Asian Scientific Research, Vol. 2, No. 5,2012, pp. 260-268.

7. Allan H. Frey, (1988) Evolution and Results of Biological Research with Low-Intensity Nonionizing Radiation, Modern Bioelectricity. 785-837, 1988.

8. R Santini, P Santini, J.M Danze, P Le Ruz, (2002) "Study of the Health of People living in the vicinity of mobile phone base stations" Influences of distance and sex, Pathol Biol 50, 2002, 369-373.

9. Nora D. Volkow, Dardo Tomasi \& Gene-Jack Wang, (2011) "Effects of Cell Phone Radiofrequency Signal Exposure on Brain Glucose Metabolism”, Journal of American Medical Association, 305(8), 2011, 808-813.

10. AM Martinez-Gonzalez, A Fernandez-Pascual, (2002) “Practical Procedure for Verification of Compliance of Digital Mobile Radio Base Stations to Limitations of 


\section{Effects of Non-Ionizing Radiation and its Health Hazards on human body}

\section{Runak Tahir Ali and Abdulrahman Khaleel}

Exposure of the General Public to Electromagnetic Fields", IEEE Proceedings on Microwaves, Antennas and Propagation (USA) 149 (2002) 218-228.

11. Barnes FS, Greenebaum B, (2007) Handbook of biological effects of electromagnetic elds: bioengineering and biophysical aspects of electromagnetic _ elds. 3rd Edition, Boca Raton, FL: CRC Taylor and Francis Press, 440.

12. Birenbaum L, Grosof GM, Rosenthal SW, Zaret MM, (1969) “Effect of microwaves on the eye. IEEE Transactions on Biomedical Engineering”, 16(1): 7-14.

13. Çam ST, Seyhan N, (2012) "Single -strand DNA breaks in human hair root cells exposed to mobile phone radiation". International Journal of Radiation Biology, 88(5): 420-424.

14. WHO Press Release, (2011) "IARC classies radiofrequency electromagnetic fields as possibly carcinogenic to humans" International Agency for Research on Cancer (IARC).

15. Schüz J, Ahlbom A. (2008) "Exposure to electromagnetic fields and the risk of childhood leukaemia": a review. Radiat Prot Dosimetry. 2008; 132(2):202-

http://www.aaronia.com/basics/limits/international-exposure-limits/ 